\title{
The Quality Standards for Probiotics in China
}

\author{
Peina Yuan* \\ National Institute for the Control of Pharmaceutical \& Biological Products, 2, Tiantan Xili, Beijing, 100050, P.R. China \\ Received November 19, 2001; Accepted for publication, March 29, 2002
}

In the past ten years, some probiotics were authorized to use for the clinical treatment of diseases caused by imbalance of intestinal flora, in China. These probiotics preparation shall meet the quality standards issued by State Drug Administration.

Key words: probiotics; quality standards

Since early 1990 s, some probiotics used for clinic treatments have been licensed to produce in China. These probiotics preparations belong to the biological products, and the quality standards shall be in accordance with requirements for biological products.

In 1995, the national tentative standards for four kinds of medicinal probiotics, including the live Bifidobacterium preparation, the live combined Bifidobacterium, Lactobacillus and Enterococcus preparation, the live Bacillus cereus preparation and the live Bacillus licheniformis preparation were established. In 2000, State Drug Administration issued the official quality standards for above 4 probiotics and another live combined Bifidobacterium, Lactobacillus and Streptococcus thermophilus tablets.

The quality standards of these preparations contain in the main, 1) descriptive definition, 2) manufacturing, 3) control tests on final products, 4) storage, transport and validity period, 5) instruction for administration.

The following is an example of a quality standards for medicinal probiotics.

\section{REQUIREMENTS FOR LIVE BIFIDOBACTERIUM PREPARATION, ORAL}

\section{Descriptive Definition}

Live Bifidobacterium preparation is a probiotics of the Bifidobacterium prepared by cultivation, cells harvest, lyophilization and mixing with auxiliary materials. It is used for the treatment of diarrhoea, constipation and endotoxemia caused by imbalance of intestinal flora.

*Corresponding author. Mailing address: National Institute for the Control of Pharmaceutical \& Biological Products, 2, Tiantan Xili, Beijing, 100050 , P.R. China. Phone: $+86-10-67017755$ ext. 420. Fax. +86-10-67024831. Email: yuanpn@public.bta.net.cn

\section{Manufacturing}

2.1 Basic requirements

2.1.1 Facilities and manufacturing management

The Chinese GMP for Pharmaceutical Products shall apply.

2.1.2 Source and subsidiary materials

The requirements of the current Chinese Pharmacopoeia or the Quality Standards for Major Source and Subsidiary Materials Used for Biologics shall apply. The chemicals not included in the above standards shall be at least of chemical pure.

2.1.3 Water for production

The source water for production shall meet the national drinking water standards.

\subsubsection{Apparatus for production}

Apparatus used directly in production shall be washed and cleaned thoroughly and sterilized.

2.1.5 Animals for production and quality control

Mice shall satisfy the standards for clean animals.

2.2 Bacterial strain for production

2.2.1 Name and origin of bacterial strain

The Bifidobacterium adolescentis X strain approved by the NCA is used to produce the Bifidobacterium preparation.

2.2.2 Establishment of the master seed lots and working seed lots of $B$. adolescentis X strain

Production of probiotics shall be based on three-tier seed lot system. The record, history, origin and biological properties of the primary seed lot shall be verified. Master seed lots shall be passaged from the primary seed lot. They shall be freeze-dried and preserved after multiplication. Working seed lots shall be prepared from master seed lots. The biological properties of master seed lots and working seed lots within designated number of passage shall be in conformity with that of the primary seed lot. Working seed lots shall be used for production. 


\subsubsection{Control test on bacterial strain}

2.2.3.1 Morphology and cultural characteristics

The colonies of $B$. adolescentis $\mathrm{X}$ strain, after cultivation on $\mathrm{BS}$ agar plate under an anaerobic condition at $37^{\circ} \mathrm{C}$ for $48 \mathrm{hr}$, shall be smooth and round and light grayish-yellow in color. The bacillus is Gram positive in forms of fine-rod by microscopic examination of stained smear.

\subsubsection{Biochemical reactions}

The cultures of $X$ strain shall ferment raffinose, ribose, lactose, melibiose, melezitose and salicin fail to ferment rhamnose and sorbitol, and shall be catalasenegative.

2.2.3.3 Toxicity test

\subsubsection{Passage of bacterial seeds}

On appropriate media, the subculture of master seed lots shall not exceed ten passages, and the subculture of working seed lots shall not exceed five passages.

\subsubsection{Storage of bacterial seeds}

The seeds shall be lyophilized and preserved at low temperature.

2.3 Powder preparation

2.3.1 Culture medium

BS broth medium or other appropriate media shall be used.

\subsubsection{Working seeds}

Lyophilized working seed lots used for the production shall be proved qualified. Section 2.2.4 of this Requirements shall apply for the passages.

\subsubsection{Preparation of seed culture}

Inoculate the working seed into the BS broth media, and incubate at $37^{\circ} \mathrm{C}$ for amplification. The amplified seed cultures shall be tested for cultural characteristics and examined microscopically by stained smear.

\subsubsection{Cultivation by fermentation}

The seed cultures qualified in control tests shall be inoculated into the fermentors. Fermentation shall be carried out at $37^{\circ} \mathrm{C}$ for a period of time. During the fermentation and at the end of fermentation samples shall be taken for microscopic examination and for bacterial purity test respectively. The contaminated cultures shall be discarded immediately.

\subsubsection{Harvest of bacterial cells}

Harvest the wet bacterial cells after centrifugation and mix them with appropriate dispersing agents.

\subsubsection{Lyophilization}

The bacterial powder shall be prepared by lyophilization.

2.4 Control test on bacterial powder

2.4.1 Inspection on final container

It is a grayish-white or a grayish-yellow powder.

\subsubsection{Bacterial purity test}

The cultural characteristics and the results of microscopic examination of stained smear of the bacteria from the powder shall be in conformity with that of $B$. adolescentis $\mathrm{X}$ strain. If there is an evidence of contaminating microorganisms shown in the powder, it shall be discarded immediately.

2.4.3 Loss on drying

It shall be not more than $5.0 \%$.

\subsubsection{Viable bacterial count}

The content of the viable bacteria in the bacterial powder shall be not less than $1.0 \times 10^{9} \mathrm{CFU} / \mathrm{g}$.

2.5 Formulation of final bulk

\subsubsection{Formulation}

The final bulk shall be formulated by mixing the bacterial powder, according to the viable bacterial count, with appropriate amount of the auxiliary. The viable bifidobacteria count in final bulk shall be not less than $1.0 \times 10^{8} \mathrm{CFU} / \mathrm{g}$.

2.5.2 Control tests on final bulk

The test of microbial contamination shall be carried out.

No pathogens such as pathogenic E. coli, Pseudomonas aeruginosa, Staphylococcus aureus, Salmonella, or Shigella, etc. shall be detected in the test. The content of non-pathogens shall be not more than 1000 cells/g, Fungi shall be not more than 100 cells/g.

2.6 Filling and specifications

0.33 gram per capsule, contains not less than $0.33 \times$ $10^{8} \mathrm{CFU}$ of viable bacterial count.

\subsection{Packaging}

The Chinese Requirement for Biological Products shall apply.

\section{Control Tests on Final Products}

\subsection{Identity tests}

The bacterial characteristics in capsules shall satisfy that of $B$. adolescentis X strain.

\subsection{Appearance}

The contents of the capsule shall be grayish-white or grayish-yellow in color.

\subsection{Weight variation}

The capsulation standards of the current Chinese Pharmacopoeia shall apply.

\subsection{Disintegration}

The capsulation standards of current Chinese Pharmacopoeia shall apply.

\subsection{Loss on drying}

It shall be not more than $5.0 \%$. 3.6 Viable bacterial count

The viable bacterial count shall be not less than 
$1.0 \times 10^{8} \mathrm{CFU} / \mathrm{g}\left(0.33 \times 10^{7} \mathrm{CFU} /\right.$ capsule $)$, and not less than $1.0 \times 10^{6} \mathrm{CFU}$ during the validity period.

3.7 Test for the presence of contaminating microorganisms

Section 2.5.2 of this Requirements shall apply.

3.8 Abnormal toxicity test

Dilute $2 \mathrm{~g}$ of final product with $8 \mathrm{ml}$ physiological saline, and orally feed each of five mice weighing 18 $22 \mathrm{~g}$ with $0.5 \mathrm{ml}$ of the diluted sample, once a day for three days continuously. It passes the test if all the mice remain healthy and gain weight from the first day to the seventh day of perfusion. If the test failed, it can be repeated once by using ten mice and the above men- tioned standards shall apply.

\section{Storage, Shipping and Validity Period}

Store and ship at $2-8^{\circ} \mathrm{C}$ and protected from light. The validity period of the product is two years, starting from the date when the test of the viable bacterial count for final product proved qualified.

\section{Package Insert}

It shall be compiled in accordance with the relevant items given in Chinese Requirements for Biological Products. 